\title{
The relationship between management styles and trainers' job motivation in the public institutions
}

\author{
Nedim Malkoc ${ }^{1}$, Suzan Dal ${ }^{2}$ \\ ${ }^{1}$ Department of Exercise and Sport Sciences, University of Health Sciences, Istanbul, Turkey \\ ${ }^{2}$ Sports Science Faculty, Istanbul University-Cerrahpasa, Istanbul, Turkey
}

\section{Article Info \\ Article history: \\ Received Jun 28, 2020 \\ Revised Dec 9, 2020 \\ Accepted Jan 23, 2021}

\section{Keywords:}

Institutions

Job motivation

Management styles

Trainers

\begin{abstract}
The study aimed to determine the relationship between perceptions of management styles and trainers' motivation in the public sports institutions, and to examine the effect of management styles on job motivation. The sample of the research consists of 190 trainers, 18 of whom are women and 172 of whom are men working in the public sports institutions. In the study, descriptive scanning method was used, and the data obtained were analyzed by making statistical procedures such as frequency, correlation, regression analysis. It was found that democratic management style and paternalist management style had a positive effect on trainers' job motivation. However, the liberal management style and authoritarian management style were found to have a negative effect on trainers' job motivation.
\end{abstract}

This is an open access article under the CC BY-SA license.

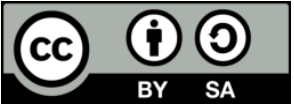

\section{Corresponding Author:}

Nedim Malkoc

Department of Exercise and Sport Sciences

Hamidiye Faculty of Life Sciences

University of Health Sciences

Istanbul, Turkey

Email: nedimmalkoc82@gmail.com

\section{INTRODUCTION}

Management as a process refers to a number of activities and functions, management as an art refers to implementation, and management as a science refers to a systematic and scientific knowledge [1]. According to these perspectives, various meanings are attributed to the concept of management. However, in its most general definition, management can be seen as a process directed to manage individuals and groups for a specific purpose [2]. In other words, management is to ensure that the organization resources reach the goals by planning [3]. Management can also be defined as the process of working with people and resources for the realization of organizational goals, for the coordination of the work with others or through others, efficiently and effectively [4].

Management style, which is a broad concept includes elements such as organization, planning, directing, coordination, control, procurement and selection, and authority sharing [5]. The most important elements that will bring an institution to success are management style and people [6]. Management style expresses the way the manager uses his/her authority over the employees and level of relationship with the employees in reaching the goals of the organization [7].

The most important factor that determines and shapes the type of management behavior is the way the manager uses his/her authority [8]. Managers are the people who keep things going through other people [9]. The manager is the person who works with others to coordinate business activities in order to achieve organizational goals [10]. Based on these explanations, it is possible to say that management style is a very 
important process in achieving organizational goals because the way managers use their powers, the level of interaction with employees, and the decisions they make regarding service and production processes affect the effectiveness and efficiency of the organization [11].

It is stated that the authority level and power of the managers of an organization are determinants in the classification of management styles that can be applied in the organization. Within the scope of evaluations, management styles are classified by researchers as: Paternalistic, democratic, laissez-faire and authoritarian management styles [12]. Paternalistic management style is about how much managers adopt paternalism.Paternalist management is defined as a management style where discipline and paternalistic intent come together [13]. Paternalistic management style is a management style that includes the manager's attention to his employees in all his business processes, helping them as much as possible and showing a father-like attitude rather than that of the manager. The rate of control is at a certain level and the communication of the managers is seen not only within the organization but also outside the organization. $[14,15]$. Paternalism is not considered to have a feature that combines paternalistic benevolent authority and discipline $[15,16]$. The characteristics of a particular culture can be a determinant of its leadership styles and the leadership styles brought about by the cultural values of various societies are quite different from each other [17]. In this context, it has been observed in intercultural studies that paternalistic leadership is seen at a higher level in China, Pakistan, India, the United States and Turkey than Germany and Israel [18].

Aycan [15] supported that paternalistic leadership style is a suitable leadership type that helps to obtain efficient and productive result in the collectivist societies like Turkey. At this point, it is important to reveal how the paternalist leadership style that we encounter as the result of a cultural phenomenon has an impact on the employees. In democratic management style, which can also be described as a participatory management style, managers expect that subordinates will work in a certain order and increase their motivation levels by appreciating successful employees. On the other hand, it takes into consideration the opinions and suggestions of subordinates in decision making processes [12]. Democratic management is an approach that constantly communicates with employees, provides effective workforce support and constant motivation to employees and reveals their talents [16]. Democratic management is also an active involvement of people in this process who report to the manager about how their work is done in their fields [17]. The emergence of positive behaviors of employees such as being a part of the team and having a sense of belonging to the organization is supported by democratic management style [18].

Authoritarianmanagement style, managers expect their subordinates to act in accordance with the determined rules, procedures, goals and policies. Also, the interaction and communication between the manager and subordinates are at very low levels. In addition, subordinates are not allowed to participate in decision making in an autocratic management. In authoritarian organizations in which management is designed hierarchically, decisions are made by the top management and are dictated without questions [19]. Authority in management continues with its employees' internal rebellion, anger, non-intentional obedience and low trust and the avoidance of the use of real performance, knowledge and ability, which leads to low quality and low performance in the organization [20].

Laissez-faire management is a style that aims to establish a minimum level of supervision on subordinates [21]. In this management style, managers avoid taking responsibilities or making decisions and they only intervene in the activities of employees when there are problems and actions are difficult to prevent [22]. This management style can result in inefficiency in cases where employees have lack of adequate knowledge, skills and experience, on the other hand it can cause performance enhancement by innovation and creativity in organizations where there is a high level of skill, knowledge and task awareness [23].

Job motivationis defined as encouraging, supporting and directing employees in order to carry out activities related to organizational goals [24]. Motivation with its broad scope and meaning is fulfilling the basic physiological needs of the employees, belonging to a group or wanting to be useful in the organization, and also it triggers the organization's desire to reach the goals in the best way. Motivation in management is used to ensure that the employee is effective and productive in business with the energy that he/she has [25].

Motivation is an important indicator for employees to be excited and determined to perform their jobs at a high level. It provides a rising level of commitment and a more personal focus on the set targets [26]. The motivation process is defined as a process for success in the business field of the individual or organization. It is to ensure that the employee strives to execute the wishes and goals of the organization and himself, and job motivation has started to attract more attention to workplaces by the day [27].

One of the most important issues in motivation is to identify the needs of employees which differ from person to person. The variety and continuity of the needs lead to the complexity and continuity of the behavior. Therefore, motivational factors and tools need to be constantly reviewed [28]. In globalizing organizations, business executives face the obligation to motivate their increasingly diverse employees [29]. Various assumptions about motivation have been put forward in different studies. For example, while Baumerster and Leary [30] emphasized that social activities may be the most important source of motivation, 
Parker [31] found that job diversity, job identity, emphasis on work, job autonomy, job demands and social support are the most important sources of motivation in an organization. In this study, management style, salary and rewarding, security, teamwork and self-development are considered as motivation tools.

Therefore, the main purpose of this study, which is carried out based on the importance of the subject and the gap in the literature, is to determine whether there is a relationship between the management styles perceived by the trainers in the public sports organization and their job motivations. In line with this general purpose, it is also to examine the effect of the management styles perceived by trainers in the public sports organizations on job motivations.

\section{RESEARCH METHOD}

\subsection{Participants}

Relational screening model was used in this study, and the sample of the study consists of 190 trainers working in Kocaeli public sports organizaton. The data were collected by simple random sampling method. A total of 190 trainers, 9.5\% $(n=18)$ women and $90.5 \%(n=162)$ men, participated in the study.

\subsection{Data collecting tools}

\subsubsection{Personal information form}

There were questions prepared by the researcher in this form that included the age, gender, marital status, educational status and working hours in order to learn the demographic information of the employees.

\subsubsection{Management styles' scale}

This scale developed by Bektaş [32] was used to measure employees' perceptions of management styles. The scale consists of 23 questions and four subscales. These are authoritarian, democratic, laissezfaire and paternalistic management styles. When considering the internal consistency of the management styles scale used in the research; paternalistic management was found to be $\alpha=0.751$, autocratic management $\alpha=0.712$, laissez-faire management $\alpha=0.790$, and democratic management style was $\alpha=0.768$.

\subsubsection{Job motivation scale}

This scale consisting of a total of 20 questions was used to measure the motivation of the employees. The motivation scale was prepared by Özgür [33]. The job motivation scale consists of five subscales which are management style, salary and rewarding, security, teamwork and self-development. Total Cronbach alpha internal consistency coefficient of the scale was found to be $\alpha=0.820$. When the subscale internal consistency coefficients of the scale was analyzed, management style was found to be $\alpha=0.812$, salary and Rewarding $\alpha=0.765$, security $\alpha=0.850$, team work $\alpha=0.824$, self-development $\alpha=0.815$.

\subsubsection{Data analysis}

SPSS 20 package program is used to analyze the data. Descriptive statistics, correlation and regression analysis are used to analyze the gathered data.

\section{RESULTS}

Demographic information about the participants was presented in Table 1. According to the results of the Table 1 the relationship between the management style scale and the job motivation scale subscale scores applied in the study was determined by Pearson correlation analysis.

According to the results of the Table 2, Paternalist management scores were found to be positively significant with the Job Motivation Scale subscales, and positively correlated with the Job Motivation scale's total scores $(\mathrm{r}=.711, \mathrm{p}<.01)$. Authoritarian management scores were negatively significant with the Job Motivation Scale subscales and it was observed that the authoritarian management score was negatively correlated with the total scores of the Job Motivation scale, significantly $(\mathrm{r}=-.569, \mathrm{p}<.01)$. It was also observed that the Laissez-faire management scores were significantly related to the Job Motivation Scale subscales in a negative way and also were negatively related to the Job Motivation scale's total scores $(\mathrm{r}=-.198, \mathrm{p}<.01)$. It was found that the Democratic management scores were significantly related to the Job Motivation Scale subscales in a positive way and were also positively related to the Job Motivation scale's total scores, significantly $(\mathrm{r}=.777, \mathrm{p}<.01)$. In this context, regression analysis was conducted on the extent to which these variables explain job motivation, which is positive with some of the management styles and negative with others. 
Table 1. Demographic information of the participants

\begin{tabular}{llcc}
\hline & Variables & $\mathrm{N}$ & $\%$ \\
\hline \multirow{4}{*}{ Gender } & Women & 18 & 9.5 \\
& Men & 172 & 90.5 \\
& Total & 190 & 100.0 \\
& Single & 120 & 63.2 \\
& Marital status & 70 & 36.8 \\
& Total & 190 & 100.0 \\
& High school and below & 26 & 13.7 \\
Educational status & Undergraduate-Graduate degree & 149 & 78.4 \\
& Postgraduate & 15 & 7.9 \\
& Total & 190 & 100.0 \\
& $20-26$ & 49 & 25.8 \\
& $27-31$ & 45 & 23.7 \\
Age & $32-36$ & 44 & 23.2 \\
& $37-41$ & 32 & 16.8 \\
& 42 and above & 20 & 10.5 \\
& Total & 190 & 100.0 \\
Working time in the & 1 year and below & 47 & 24.7 \\
organization & $1-5$ & 115 & 60.5 \\
& 5 years and above & 28 & 14.7 \\
& Total & 190 & 100.0 \\
\hline
\end{tabular}

Table 2. Correlation analysis of job motivation and management style

\begin{tabular}{|c|c|c|c|c|c|c|c|c|c|c|}
\hline \multirow{4}{*}{ MSS } & Paternalistic & 1 & & & & & & & & \\
\hline & Autocratic & $-0.555^{* *}$ & 1 & & & & & & & \\
\hline & Laissez-faire & $-0.276^{* *}$ & $0.549^{* *}$ & 1 & & & & & & \\
\hline & Democratic & $0.805^{* *}$ & $-0.676^{* *}$ & $-0.396^{* *}$ & 1 & & & & & \\
\hline \multirow{6}{*}{ BMS } & Management style & $0.792^{* *}$ & $-0.596^{* *}$ & $-0.270^{* *}$ & $0.842^{* *}$ & 1 & & & & \\
\hline & Salary and R. & $0.487^{* *}$ & $-0.362^{* *}$ & -0.010 & $0.506^{* *}$ & $0.659^{* *}$ & 1 & & & \\
\hline & Security & $0.473^{* *}$ & $-.415^{* *}$ & -0.106 & $0.552^{* *}$ & $0.638^{* *}$ & $0.744^{* *}$ & 1 & & \\
\hline & Team Work & $0.642^{* *}$ & $-0.535^{* *}$ & $-0.187^{* *}$ & $0.721^{* *}$ & $0.785^{* *}$ & $0.588^{* *}$ & $0.663^{* *}$ & 1 & \\
\hline & Self-development & $0.755^{* *}$ & $-0.614^{* *}$ & $-.334^{* *}$ & $0.820^{* *}$ & $0.881^{* *}$ & $0.670^{* *}$ & $0.649^{* *}$ & $0.776^{* *}$ & 1 \\
\hline & Total & $0.711^{* *}$ & $-0.569^{* *}$ & $-0.198^{* *}$ & $0.777^{* *}$ & $0.899^{* *}$ & $0.850^{* *}$ & $0.855^{* *}$ & $0.865^{* *}$ & $0.901^{* *} \quad 1$ \\
\hline
\end{tabular}

According to the results of the Table 3, In order to determine whether the management style's scale scores applied in the study which predicts the job motivation scale's total scores, the total scores of the job motivation scale were determined as dependent variables, and paternalistic management, authoritarian management, laisse-faire management and democratic management scores were determined as independent variables and standard multiple regression analysis was applied. In the simple linear regression model in which all independent variables are included in equation (Enter); It was determined that it significantly predicted the Job Motivation total scores [F 4,185=85.752, p<.01]. In the model, $65 \%$ of the variance in the Job Motivation total scores are explained $(\mathrm{R} 2=.650)$. When the standardized regression coefficients are examined; According to the power of predicting Job motivation; It was observed that democratic management scores $(\beta=.560, \mathrm{p}<.01)$, laisse-faire management scores $(\beta=.175, \mathrm{p}<.01)$ and paternalist management scores $(\beta=.217, \mathrm{p}<.01)$ positively; while Authoritarian Management scores $(\beta=-.167, \mathrm{p}<.05)$ negatively predicted job motivation. In the light of these findings, $\mathrm{H} 1, \mathrm{H} 2$ hypotheses were accepted and $\mathrm{H} 3$, H4 hypotheses were rejected.

Table 3. Regression analysis on the prediction of job motivation by management styles

\begin{tabular}{lcccc}
\hline & $B$ & $\beta$ & $t$ & $p$ \\
\hline Constant & 0.632 & & 1.927 & 0.055 \\
Paternalistic Management & 0.180 & 0.217 & 2.944 & 0.004 \\
Autocratic Management & -0.149 & -0.167 & -2.561 & 0.011 \\
Laissez-faire Management & 0.187 & -0.175 & 3.345 & 0.001 \\
Democratic Management & 0.552 & 0.560 & 6.730 & 0.000 \\
\hline$R=.806 R^{2}=.650 R^{2}{ }_{a d j}=.642, F$ & $4,185=85.752, p<.01$ & & \\
Dependent Variable: Job Motivation (Total) & &
\end{tabular}

\section{DISCUSSION}

The research was carried out on 190 trainers (18 Women, 172 Men) working in the public sports organization. As a result of the correlation analysis, it was observed that there was a positive and significant 
correlation between the paternalistic management style and democratic management style and job motivation scale subscales and total scores of the job motivation scale. In addition, it was observed that there was a significant negative relationship between the trainers' autocratic management style and laissez-faire management style and the job motivation subscales and total scores.

Based on the motivation approaches, learning the sources of motivation in the organization where the participants work will contribute to the management. From the results obtained in the study, it was found that the paternalistic management style and democratic management style positively affect the motivation of the trainers in the public sports organization. These results indicate that the perceived management style is a variable that may affect the job motivation of the tariners. In the literature, there are findings supporting this opinion. In the study findings of $\mathrm{Nal}$ and Sevim [34], it has been determined that paternalist leadership has a significant and positive effect on the external motivation of the trainers. Paternalist management style encourages subordinates' business identity and reveals their motivation. In other words, it is the leadership style that reveals the motivation of the employee [35]. In addition, it has been determined in the studies that there are relationships between paternalistic leadership and employees' creative participation perception, organizational commitment, employee performance, organizational citizenship, job satisfaction and job gratification [36, 37]. Aycan [15] argues that paternalistic leadership style is a suitable leadership type which helps to obtain efficient and productive results in a collectivist society like Turkey. The result of Aycan's study confirms similarly, that human relations are given importance in the democratic management style. An environment where employees are constantly suppoted and motivated is created. Also, their inclusion in decision making processes is an important source of motivation [38]. Besides, it has been observed that Democratic management Style has an impact on positive organizational behavior issues like; business performance, organizational commitment, creativity, job satisfaction. [39]. Democratic management style is known to appeal to the internal motivation of employees, particularly when it is practised through an effective management way [40].

It was also observed that there is a negative relationship between autocratic management style and laissez-faire management style and job motivation subscales and total scores. In the autocratic management approach, the manager usually shows an authoritarian behavior by accepting man as a passive element that fits the organizational goals. Therefore, management styles such as strict control, very little delegation, detailed job descriptions and detailed penalty are adopted [2]. Managers with a democratic or authoritarian management understanding leaves positive or negative effects on employees [41]. It was found that the motivations of the trainers of the public sports organizations which constitute the sample of this study, were negatively affected by an autocratic management style. Similarly, in environments where the laissez-faire management model is utilized, there is an inverse relationship between employee efforts and motivations [42]. The laissez-faire management style makes little contribution to employees. The use of authority in laissez-faire leadership is completely eliminated [43]. This management model also shows that it affects the motivation of the individuals working in sports organzation negatively just like the authoritarian management model where authority is very high. Another aspect to be put into consideration in this study, is the ability to know to what extent the trainers' perceptions of management style affect their job motivation. It was observed from the regression analysis that the management style has $65 \%$ explanation for job motivation, and that democratic management and paternalistic management styles have the power of predicting job motivation positively, while laissez-faire management and authoritarian management styles predict negatively.

A proper examination of the literature reveals that there is no general and single management style that can be applied in organizations. However, it is observed that management style can change depending on many factors and different management styles can be applied [44]. In summary, when the research findings were evaluated together with the different results obtained in previous studies, results show that there is a difference between the best management style, the best organizational structure and the motivation techniques [45], and that the paternalistic management style and the democratic management style, which are more appropriate in the Turkish social structure, positively affect the motivation of the trainerss in sports organization.

\section{CONCLUSION}

The perceived management styles by the employees in public sports institutions have an impact on job motivations. As a result of the study, it was emphasized that the work motivations of the employees in public sports institutions were affected by different management styles.

In this context, while the Paternalist Management Style and Democratic Management Style are affecting the business motivations positively, the Autocratic Management Style and the Laissez-faire Management Style have been found to affect the business motivations negatively. Again, within the scope of this study, it has been determined that the most appropriate management style will differ for increasing the motivation of the employees. The researcher attributes the reason for these results to the fact that the study 
was streamlined to thetariners of the public sports organization. In order to obtain more inclusive and healthy results with similar studies, it would be appropriate to carry out the studies on this subject in different organizations and places in the future.

\section{REFERENCES}

[1] A. Baransel, Çağdaş Yönetim Düşüncesinin Evrimi, Klasik ve Neoklasik Yönetim ve Örgüt Teorileri, Cilt-1. İstanbul Üniversitesi Yayını, 1979.

[2] T. Koçel, İşletmeyöneticiliği. Eskişehir, 2000.

[3] R. L. Daft and D. Marcic, Management: The new workplace. Evans Publishing Group, 2008.

[4] S. Bateman, Management. New York: Mcgraw Hill, 2013.

[5] W. Y. Wu, C. Y. Chiang, and J. S. Jiang, "Interrelationships between tmt management styles and organizational innovation," Industrial Management \& Data Systems, vol. 102, no. 3, pp. 171-183, 2002.

[6] B. Donuk, Tam yol yönetim, Cagdas Spor Yönetim Ilkeleri. Istanbul: Ötüken Neşriyat, 2019.

[7] N. Ucheand and C. O. Timinepere, "Management styles and organizational effectiveness: an appraisal of private enterprises in Eastern Nigeria," American International Journal of Contemporary Research, vol. 2, no. 9, pp. 198-204, 2012.

[8] A. R. Terzi and T. Kurt, "İlköğretim okulu müdürlerinin yöneticilik davranışlarının öğretmenlerin örgütsel bağlılığına etkisi,” Milli Eğitim, vol. 166, no. 33, pp. 98-111, 2005.

[9] S. P. Robbins and T. Judge, Organizational Behavior. New Jersey: Pearson, 2007.

[10] S. P. Robbins, D. A. Decenzo, M. Coulter, and I. Anderson, Fundamentals of management. New Jersey: Pearson, 2014.

[11] M. T. Pop and D. Pop, "Types of managers and management styles," Fascicle of Management and Technological Engineering, vol. 7, no. 17, pp. 2604-2610, 2008.

[12] B. Scott-Laddand and B. Marshall, "Participation in Decision Making: A Matter of Context?" Leadership \& Organization Development Journal, vol. 25, no. 8, pp. 646-662, 2004.

[13] J. L. Farh and B. S. Cheng, "A cultural analysis of paternalistic leadership in Chinese organizations," Management and Organizations In the Chinese Context, pp. 84-127, 2000.

[14] H. Anwar, "Impact of paternalistic leadership on employees' outcome-a study on the banking sector of Pakistan," Journal of Business and Management, vol. 7, no. 6, pp. 109-115, 2013.

[15] Z. Aycan, R. Kanungo, M. Mendonca, K. Yu, J. Deller, G. Stahl, and A. Kurshid, "Impact of culture on human resource management practices: a 10-country comparison," Applied Psychology, vol. 49, no. 1, pp. 192-221, 2000.

[16] A. Ş. İzgören, Geleceğin organizasyonunu yaratmak. Elma Yay, 2005.

[17] G. Fuller, Management. London: Prentice Hall Pres, 2005.

[18] H. Martin and K. Edwards, "The interaction between leadership styles and management level, and their impact on project success," Proceedings of International Structural Engineering and Construction, vol. 3, no. 2, 2016, pp. 1-6.

[19] A. Taylor, "Perspectives on the university as a business: the corporate management structure, neoliberalism and higher education," Journal for Critical Education Policy Studies, vol. 15, no. 1, pp.108-135, 2017.

[20] B. Özgür, "Yönetimtarzlarıveetkileri", Maliye Dergisi, vol. 161, pp. 215-230, 2011.

[21] M. Diebig, K. C. Bormann, and J. Rowold, "A double-edged sword: relationship between full-range leadership behaviors and followers' hair cortisol level,” The Leadership Quarterly, vol. 27, no. 4, pp. 684-696, 2016.

[22] X. X. Che, Z. E. Zhou, S. R. Kessler and P. E. Spector, "Stressors beget stressors: the effect of passive leadership on employee health through workload and work-family conflict," Work \& Stress, vol. 31, no. 4, pp. 338-354.

[23] A. L. Steinke, "Management styles and innovation in the technology industry," Doctoral Dissertation, The College of St. Scholastica, 2013.

[24] G. Akbaş, "Servis hemşirelerinin stress ve motivasyon düzeylerinin belirlenmesi," Doctoral Dissertation, Sağlık Bilimleri Enstitüsü, 2007.

[25] Ö. Peker and N. Aytürk, Etkili yönetim becerileri. Ankara: Kitap Dostu, 2000.

[26] G. Gökçe, A. Şahin, and Y. Bulduklu, "Herzberg'inçift faktör kuramive alt gelirgrup larindabiruygulama: meram tip fakültesiörneği," Sosyal Ekonomik Araştirmalar Dergisi, vol. 10, no. 20, pp. 233-246, 2010.

[27] K. Kaymaz, "The effects of job rotation practices on motivation: a research on managers in the automotive organizations," Business and Economics Research Journal, vol. 1, no. 3, pp. 69-85, 2010.

[28] A. Karakaya and F. A. Ay, "Çalişan larin motivas yo nunuetkileyen faktörler: sağlik çalişan larina yö nelik biraraştirma," C..Ü. Sosyal Bilimler Dergisi, vol. 31, no. 1, pp. 55-67, 2007.

[29] H. Y. Chen and H. S. R. Kao, "Chinese paternalistic leadership and non-chinese subordinates' psychological health," The International Journal of Human Resource Management, vol. 20, no. 12, pp. 2533-2546, 2009.

[30] R. F. Baumeister and M. R. Leary, "The need to belong: desire for interpersonal attachments as a fundamental human motivation," Psychological Bulletin, vol. 117, no. 3, pp. 497, 1995.

[31] S. K. Parker, "Beyond motivation: job and work design for development, health, ambidexterity, and more," Annual Review of Psychology, vol. 65, pp. 661-691, 2014.

[32] M. Bektaş, "Yönetim tarzlarının örgütlerdeki informal iletişim kanallarına etkisi: burdurilikamukurumları örneği," Doctoral Dissertation, Süleyman Demirel Üniversitesi Sosyal Bilimler Enstitüsü, 2014.

[33] E. Özgür, "Performans yönetimi ile motivasyon ilişkisibiruygulama, Atatürk üniversitesi sosyalb ilimler enstitüsü," Master's Thesis, İşletme Anabilim Dalı, Erzurum, 2006.

[34] M. Nal and E. Sevim, "Paternalist liderliğin iş motivasyonu üzerine etkisi: sağlık çalışanları üzerinde bir araştırma," Gümüşhane Üniversitesi Sağlık Bilimleri Dergisi, vol. 8, no. 4, pp. 397-410, 2019. 
[35] C. H. Fang, C. L. Fang, R. F. Chao, and S. P. Lin, "Paternalistic leadership and employees' sustained work behavior: a perspective of playfulness," Sustainability, vol. 11, no. 23, pp. 6650, 2019.

[36] E. Tekin, "Paternalist liderliğin iş tatminiv eçalışan performansına etkisi üzerinebiraraştırma," Third Sector Social Economic Review, vol. 54, no. 1, pp. 178-204, 2019.

[37] E. Koç and A. Alpullu, "Gençlik vesporilmüdürlüğü çalışanlarının iş doyumuile paternalist liderlikar asındak iilişkinin incelenmesi,” Spor Ĕ̌itim Dergisi, vol. 3, no. 2, pp. 33-43, 2019.

[38] C. Serinkan, Liderlik ve motivas yongeleneksel ve güncel yaklaşımlar. Ankara: Nobel YayınDağıtım, 2008.

[39] P. Başar, "Katılımcı yönetimin iş doyumu üzerine etkisi: akademik personel üzerinde bir araştırma," Ekonomi İsletme Siyaset Ve Uluslararası İlişkiler Dergisi, vol. 3, no. 1, pp. 1-34, 2017.

[40] S. C. Özoral, "Demokratik yönetiman layişininişletmeler demotivas yonüzerineetkisi," Master's thesis, Beykent Üniversitesi, İşletme Yönetimi Anabilim Dali, 2010.

[41] H. Özganand N. Aslan, "İlköğretimo kulmüdürlerinin sözlü iletişim biçiminin öğretmenlerin motivasyonuna etkisinin incelenmesi," Gaziantep Üniversitesi Sosyal Bilimler Dergisi, vol. 7, no. 1, pp. 190-206, 2008.

[42] Y. Tezcan, "Liderliğin çalı̧̧anların motivasyonu üzerindeki etkisi," Doctoral Dissertation, Deü Sosyal Bilimleri Enstitüsü, 2006.

[43] E. Aykan, "Kayseri’de faaliyet gösteren girişimcilerin liderlik özellikleri," Erciyes Üniversitesi Sosyal Bilimler Enstitüsü Dergisi, vol. 1, no. 17, pp. 213-224, 2004.

[44] P. S. Poon, F. U. Evangelista, and G. Albaum, "A comparative study of the management styles of marketing managers in australia and the people's Republic of China," International Marketing Review, vol. 22, no. 1, pp. 34-47, 2005.

[45] A. Şahin, "Yönetim kuramları ve motivasyon ilişkisi," Selçuk Üniversitesi Sosyal Bilimler Enstitüsü Dergisi, vol. 11 , pp. 523-547, 2004 